\title{
Studies on Characterisation of Combined Pulsed Electric Field and Microwave Extracted Pectin from Jack Fruit Rind and Core
}

\author{
A. M. Nandhu Lal*, M. V. Prince and R. Sreeja \\ Department of Processing and Food Engineering, Kelappaji College of \\ Agricultural Engineering and Technology, Kerala Agricultural University, \\ Tavanur - 679 573, Kerala, India \\ *Corresponding author
}

Keywords

Pectin, Jackfruit, Pulsed electric field, Microwave extraction, Byproduct utilisation

\section{Article Info}

Accepted: 15 February 2020 Available Online: 10 March 2020

\section{A B S T R A C T}

Value addition of inedible parts of Jackfruit such as rind and core using efficient and environment friendly methods would reduce wastage, and its disposal problem and also fetch additional profit to farmers. Pectin, a secondary food ingredient used as gelling, stabilizing and emulsifying agent in food products is such a valuable by-product having nutritional as well as health benefits. Conventional extraction method includes direct boiling using acidified water, which is time consuming and degrades quality pectin. Application of combined novel technologies might help in conquering the inadequacies of conventional methods. A combination of pulsed electric field treatment and microwave treatment was analyzed for extraction of pectin and was compared with conventionally extracted pectin. The results of characterization and comparison studies revealed that Pulsed electric field and microwave assisted extraction resulted in extraction of better quality pectin with acceptable quality.

\section{Introduction}

Jackfruit (Artocarpus heterophyllus) is a fruit crop widely distributed in India and is fast becoming prevalent among the length and breadth of the world. India is the second largest producer of jackfruit in the global scenario and is believed to be the motherland of Jackfruit. In India, Jackfruit is cultivated approximately over an area of 1,02,552 ha, of which, approximately $1,00,000$ trees are grown as intercrop in back yards along with commercial crops. Kerala owns the largest area under Jackfruit cultivation of about 97,540 ha and produces around 348 million tons of Jackfruit (APAARI. 2012). 
Inbaraj and Sulochana (2006) reported that about $59 \%$ of ripe Jackfruit peel generally discarded as waste, which might cause serious environmental problems during the season. In India, about $75 \%$ of Jackfruit gets wasted wherein a whopping loss of 35 crore on Jackfruit accounts annually in Kerala alone. Assuming only Rs. 3/- for one Jackfruit and wastage of $50 \%$ per year, India still accounts for a loss of Rs. 214 crore worth of food every year. (www.decanherald.com).By-product recovery from such fruit wastes not only improve overall economy of the processing units but also reduce the problem of environmental pollution.

Pectin are a family of complex polysaccharides that contain 1-4 linked $\alpha$-D galacturonic acid organised in a linear backbone. Pectin is recognised as a secondary food ingredient extensively used as gelling, stabilizing and emulsifying agent in food products. Consumption of this polysaccharides has positive effects on human health as they help in reducing cancer development, lowering blood glucose and blood cholesterol level (Jackson et al., 2007). Texturizing applications of pectin in food and similar systems, includes gelling, colloid stabilizing, and viscosity enhancement are fundamentally related to its in-solution (gels or dispersions) behaviour (Lopes da Silva and Rao, 2006). Food sectors like dairy, bakery, and nutraceutical and functional foods as well as pharmaceutical domains like drug delivery uses pectin (Liu, et al., 2007; Phillips \& Williams, 2009; Schmidt et al., 2015).

Pectin polysaccharides are of high molecular weight and closely connected with other polymer components in cell walls, which inhibit their release from the cell matrix (Kratchanova et al., 2004). Therefore, the methods used for extraction should allow selective extraction of pectin and should be able to protect the molecular structure without any degradation. Pectin is obtained commercially by using heat treatment by direct boiling method (Li et al., 2012). This method is not only time consuming but also results in degradation of extracted pectin, which leads to undesired alteration in physicochemical and functional properties of pectin. Therefore, establishment of new methods are essential, by which pectin could be extracted in a shorter time with better quality. This work aims in the extraction and characterization of pectin from Jackfruit rind and core using combined Pulsed Electric Field and Microwave assisted process and comparison of the same with that obtained through conventional process.

\section{Materials and Methods}

\section{Sample collection}

Freshly harvested raw Jackfruit (Varikka variety) purchased from farm of KCAET, Tavanur were used for this study. The Jackfruit was cut using a stainless steel knife and its core (axis) and inner perigones were separated manually. These were then dried in a cabinet drier at $60{ }^{\circ} \mathrm{C}$ for 6 hours. The dried plant material is ground in a lab pulveriser mixer and stored in LDPE pouches at ambient temperature for further analysis.

\section{Preparation of alcohol insoluble solids}

The alcohol insoluble solids (AIS) from Jackfruit rind and core were prepared by treating the Jackfruit powder with $80 \%$ ethanol for 45 minutes at 1:4 (Jackfruit powder: ethanol) ratio. This procedure is repeated again and unwanted pigments, free sugars and alcohol soluble impurities from jackfruit powder were removed. The treated powder is then dried in an oven at $55^{\circ} \mathrm{C}$ until constant weight is achieved. Ten gram of this alcoholic insoluble residue is mixed with 200 $\mathrm{ml}$ of $1 \%$ citric acid solution until $\mathrm{pH} 2.0$ is 
reached, mixed well and is used for each treatment.

\section{Combined pulsed electric field and microwave assisted extraction of pectin}

The prepared AIS samples were then exposed to pulsed electric field (PEF) for 5 minutes in pulsed electric field generator developed at the institute at pulsed electric field strength of $10 \mathrm{kV} / \mathrm{cm}$. After treatment, the sample is subjected to microwave treatment in a microwave reactor for $10 \mathrm{~min}$ at a microwave power level of $650 \mathrm{~W} / \mathrm{g}$. The sample is then allowed to cool for 5 minutes at room temperature.

\section{Alcoholic precipitation of pectin}

Alcoholic precipitation of pectin was carried out using method by Kratchanova et al., (2004) with slight modifications. The cooled treated sample was added with equal amount of $95 \%$ ethanol. The mixture was stirred for 30 min using magnetic stirrer at room temperature and then kept under refrigeration at $5{ }^{\circ} \mathrm{C}$ for $1.5 \mathrm{~h}$. The coagulated pectin was then separated by filtration. This extracted pectin was washed again with $80 \%$ ethanol two times until all impurities are removed. The pectin concentrate obtained after extraction is dried in a hot air oven at $70{ }^{\circ} \mathrm{C}$ for 6 hours. The yield of powder so obtained is calculated using the following equation;

Yield of pectin $=$

weight of pectin obtained

weight of alcoholicinsoluble solid X 100

Characterization of pectin extracted by combined PEF and microwave assisted process

\section{Moisture content}

Moisture content was determined by the method suggested by AOAC (2000). Three gram of sample was weighed in a petri dish and placed in oven and dried at $105{ }^{\circ} \mathrm{C}$ for 3 hours. Weight after drying was taken. The moisture content (wet basis) in the sample was measured using the formula,

Moisture $(\mathrm{wb} \%)=\frac{\frac{\mathrm{w} 1-\mathrm{w} 2}{\mathrm{w} 1}}{\mathrm{x}} \times 100$

Where, $\mathrm{W}_{1}=$ weight of sample before drying; $\mathrm{W}_{2}=$ weight of sample after drying

\section{Solubility}

Solubility of dry pectin was found using method explained by Lokhande et al., (2016). Solubility of dry pectin in cold and hot water were found out by adding $0.5 \mathrm{~g}$ sample of dried pectin to $10 \mathrm{ml}$ of $95 \%$ ethanol in conical flask followed by addition of $50 \mathrm{ml}$ distilled water. The visual appearance of the pectin in cold water was noted. The mixture was then shaken vigorously to form a suspension and then heated at $85-90{ }^{\circ} \mathrm{C}$ for 15 $\mathrm{min}$. After heating, the visual appearance of pectin was noted for solubility of pectin in hot water.

Solubility of pectin solution in cold and hot alkali were found out as follows. Two conical flasks containing $10 \mathrm{ml}$ of $0.1 \mathrm{~N} \mathrm{NaOH}$ solution was taken and added with $5 \mathrm{ml}$ of pectin solution $(0.5 \mathrm{~g}$ dried pectin sample in $10 \mathrm{ml}$ of $95 \%$ ethanol). The visual appearance of the pectin in cold alkali was noted. The second flask was then heated at $85-90{ }^{\circ} \mathrm{C}$ for $10 \mathrm{~min}$. After heating, the visual appearance of pectin was noted for solubility of pectin in hot alkali.

\section{Viscosity}

The viscosity of pectin powder was measured using Brookfield DV-E Viscometer. The instrument measures the force quintessential for overcoming the resistant force. Spindle LV-1 (61) was selected for viscosity 
measurement of $500 \mathrm{ml}$ aqueous solution of pectin at a speed of $100 \mathrm{rpm}$. The viscosity values in centi poise were obtained.

\section{Colour}

The colour of the pectin was found using a Hunter lab colour flex meter (Hunter Association laboratory, Inc., Reston, Virginia, USA; model: Hunter-Lab's Colour Flex EZ). ' $L^{*}$ ', ' $a^{*}$ ' and ' $b^{*}$ ' values of obtained pectin samples were recorded.

\section{Ash content}

Ash content was determined by procedure as specified by AOAC (2000). About $5 \mathrm{~g}$ of sample was taken in silica dish. The dried sample and dishes were ignited on a Bunsen burner. The samples were then heated in muffle furnace at $550{ }^{\circ} \mathrm{C}$ for 4-6 hours and cooled overnight. The dishes were then cooled and weighed. The difference in weight gives total ash content of the sample in percentage.

\section{Crude protein content}

The crude protein content present in the sample was calculated by AOAC, 2005 using micro Kjeltec distillation apparatus. Finely grounded sample $(0.8 \mathrm{~g})$ was taken into the digestion tube. Digestion mixture $(0.8 \mathrm{~g}$ copper sulphate and $7 \mathrm{~g}$ of potassium sulphate) was prepared by mixing the above mentioned compounds. Sample along with 0.5 $\mathrm{g}$ of this digestion mixture is added to $10 \mathrm{ml}$ of conc. $\mathrm{H}_{2} \mathrm{SO}_{4}$. This mixture was digested in the digestion unit until the mixture became colourless. The tubes were then allowed to cool. The mixture was then transferred to distillation unit were $40 \mathrm{ml}$ of $\mathrm{NaOH}(40 \%)$ solution was endorsed into the tube. The liberated ammonium was absorbed by (4\%) boric acid solution mixed with $10 \mathrm{ml}$ bromocresol green and $7 \mathrm{ml}$ of methyl red indicator. The pink colour of this solution turns to green. This solution was then titrated against $0.1 \mathrm{~N}$ HCL until a pink colour appears. The protein percentage was calculated using the formula:

Protein $(\%)=$

$\underline{\text { (ml of HCl-ml of blank) x molarity x } 14.007 \times 100}$

mg test protein

x 6.25

\section{Equivalent weight}

One gram of pectin sample was taken in a conical flask and mixed with $5 \mathrm{ml} 95 \%$ ethanol followed by addition of $1 \mathrm{~g}$ of $\mathrm{NaCl}$. Hundred $\mathrm{ml}$ of distilled water was added to the mixture and mixed thoroughly. Few drops of phenol red indicator was added to the solution and titrated against $0.1 \mathrm{~N} \mathrm{NaOH}$ solution until the pink colour appears. The equivalent weight is then found using the formula:

Moles of $\mathrm{NaOH}=($ Titre value) $\times 1 / 1000$ $(\mathrm{ml} / \mathrm{L}) \times 0.1104 \mathrm{~mol}(\mathrm{NaOH} / \mathrm{L})$

Equivalent weight $(\mathrm{g} / \mathrm{mol})=$ weight $/$ no. of moles of $\mathrm{NaOH}$

The neutralized solution so obtained as above is referred to as Titration (A) and is used for methoxyl percentage determination.

\section{Methoxyl percentage}

Twenty five $\mathrm{ml}$ of $0.25 \mathrm{~N} \mathrm{NaOH}$ solution was added to neutralized solution (Titration A) followed by vigorous stirring using shaker and was allowed to stand for $30 \mathrm{~min}$ at room temperature. After $30 \mathrm{~min}, 25 \mathrm{ml}$ of $0.25 \mathrm{~N}$ $\mathrm{HCl}$ was added to this solution and titrated against $0.1 \mathrm{~N} \mathrm{NaOH}$ solution until color of indicator turns pink. Methoxyl content is determined by the following formula. 
Methoxyl content $(\%)=$

(ml of alkali x Normality of alkali x 3.1)

(Weight of sample)

\section{Anhydrouronic Acid (AUA) content}

The anhydrouronic acid content was calculated by applying the values of previously determined equivalent weight and methoxyl percentage to the following equation.

AUA $\%=[176 / \mathrm{Z}] \times 100$

Where, $176=$ molecular weight of anhydrouronic acid;

$\mathrm{Z}=($ weight of sample $(\mathrm{mg})) /(\mathrm{m}$ eq of alkali for free acid $+m$ eq of alkali formethoxyl)

\section{Degree of esterification}

The DE (\%) of extracted pectin was calculated using the data obtained from methoxyl and anhydrouronic acid content determinations to the following formula.

$\mathrm{DE} \%=[(176 \times \mathrm{MeO} \%) /(31 \times \mathrm{AUA} \%)] \mathrm{x}$ 10

The extraction process parameters and quality attributes of the pectin obtained through conventional extraction method and combined PEF and microwave assisted extraction process were then compared through analysis of the results obtained.

\section{Results and Discussion}

The yield of pectin after combined pulsed electric field and microwave assisted extraction yielded $18.3 \%$ at an extraction time of $15 \mathrm{~min}$ whereas conventional extraction yielded $17.1 \%$ pectin after $45 \mathrm{~min}$ of extraction. The obtained pectin powder after conventional extraction and combined PEF and microwave extraction processes are shown in Figure 1 (B) and Figure 1 (C) respectively.

\section{Physicochemical characteristics of extracted pectin}

The physicochemical characteristics of pectin obtained through combined Pulsed electric field and Microwave extraction and through conventional extraction from Jackfruit rind and core powder are shown in Table 1.

The lowest moisture content of $8.95 \%$ (wb) was observed in combined PEF and microwave assisted extraction indicating its storage stability compared to that produced by conventional extraction process. The moisture content of the extracted pectin samples were in the acceptable range (below $12 \%$ ) for both extraction processes, which satisfies the requirements suggested by Food Chemical Codex. Higher moisture content in pectin causes production of pectinase enzyme, which could initiate microbial growth and results in quality deterioration of pectin (Muhamadzadeh et al., 2010; Ismail et al., 2012).

All tested pectin samples were insoluble in cold water, but soluble in hot water. The solubility of pectin in hot water is essential during the preparation of products like jams, where pectin is used as gelling agent. All samples were partially soluble in cold alkali with the formation of precipitate. The pectin samples obtained from various extraction methods were soluble in hot alkali and the powder gets suspended in the alkali solution. Fishman (1993) reported the solubility test in alkali for pectin as a conformation test for pectin in solution. The pectin obtained from combined extraction method using PEF and microwave satisfies this conformation test. 
The results of viscosity of $2 \%$ aqueous solution of pectin indicates that viscosity of pectin obtained from combined $\mathrm{PEF}$ and microwave assisted extraction is higher than that of conventional extraction method. Increase in viscosity might be due to low exposure to heat. Higher viscosity indicates higher molecular weight, which indicates that the extracted pectin is of better grade (Rao, 1993).

Colour of pectin is an important factor as it affects the colour of final product prepared using pectin. The colour of pectin mainly depends upon the raw material and method of extraction (Mohamed and Hasan, 1995). The pectin extracted by combined $\mathrm{PEF}$ and microwave assisted extraction was light brownin colour, whereas conventional extraction method produced dark brown colour, which indicates better acceptability of combined PEF and microwave extracted pectin. Lighter colour indicates minimal effect of heat during extraction on the colour of pectin and thus preferred (Kohet al., 2014). The lowest ash content of $6.78 \%$ was observed in combined PEF and microwave assisted extraction, which was lower than pectin obtained through conventional extraction $(7.27 \%)$. The results showed that the ash content of the extracted pectin samples using both extraction techniques are in the acceptable range (below $10 \%$ ), which satisfies the requirements suggested by FAO.Yapo (2019) reported the reduction in ash content in pectin as an indication of purity of pectin contributing to good gelling strength. Lower values of pectin obtained through combined PEF and microwave assisted extraction indicates that the pectin extracted is superior in quality.

The lowest crude protein content of $3.283 \%$ was observed in combined PEF and microwave assisted extraction, which was lower than that of pectin obtained through conventional extraction (9.98\%), indicating better quality of pectin.

Table.1 Physico chemical characteristics of extracted pectin

\begin{tabular}{|c|c|c|}
\hline Test & $\begin{array}{c}\text { Conventional } \\
\text { extraction }\end{array}$ & $\begin{array}{c}\text { PEF and MW assisted } \\
\text { extraction }\end{array}$ \\
\hline Moisture content $(\boldsymbol{\%})$ & 10.04 & 8.95 \\
\hline Solubility in cold water & Insoluble & Insoluble \\
\hline Solubility in hot water & Soluble & Soluble \\
\hline Solubility in cold alkali & Soluble with precipitate & Soluble with precipitate \\
\hline Solubility in hot alkali & Soluble & Soluble \\
\hline Viscosity $(\mathbf{c P})$ & 38.14 & 39.78 \\
\hline L* & 56.61 & 73.63 \\
\hline $\mathbf{a}^{*}$ & 8.44 & 5.88 \\
\hline b* & 17.06 & 16.59 \\
\hline Ash $(\boldsymbol{\%})$ & 7.27 & 6.78 \\
\hline Protein(\%) & 9.98 & 3.283 \\
\hline
\end{tabular}


Table.2 Quality characteristics of extracted pectin

\begin{tabular}{|c|c|c|}
\hline Type of extraction & Conventional extraction & $\begin{array}{c}\text { PEF and MW assisted } \\
\text { extraction }\end{array}$ \\
\hline Equivalent weight (g/mol) & 466.905 & 557.473 \\
\hline Methoxyl percentage (\%) & 9.376 & 8.37 \\
\hline Anhydrouronic acid (\%) & 67.85 & 69.44 \\
\hline Degree of esterification (\%) & 78.45 & 68.43 \\
\hline
\end{tabular}

Figure.1 (A) Raw Jackfruit powder; (B) Pectin extracted through conventional extraction process; (C) Pectin extracted through combined Pulsed Electric Field and microwave assisted extraction process

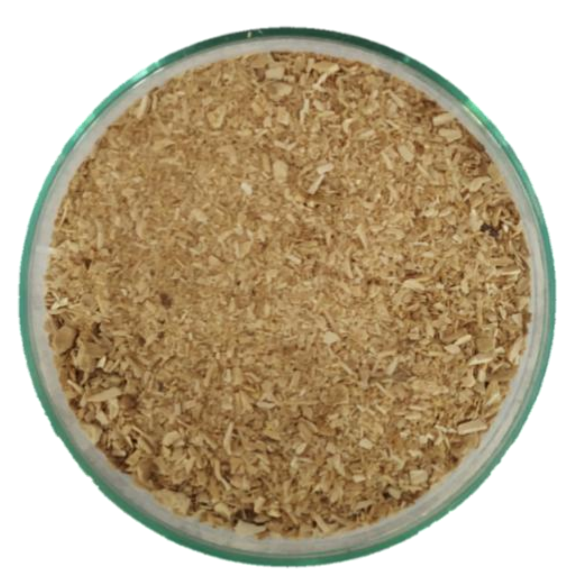

(A)

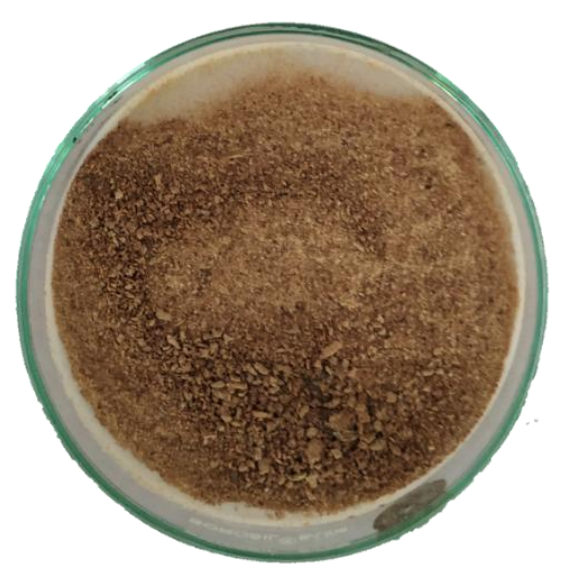

(B)

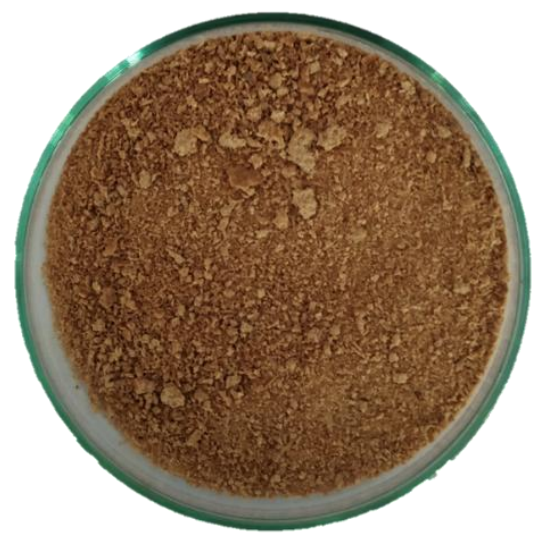

(C)

\section{Quality characteristics of extracted pectin}

The quality characteristics of pectin obtained through combined Pulsed electric field and Microwave extraction and through conventional extraction from Jackfruit rind and core powder are shown in Table 2.

Equivalent weight of pectin is the total amount of unesterified free galacturonic acid 
in the molecular chains of pectin (Ranganna, 1986). The results indicated that pectin extracted through combined PEF and microwave extraction has higher equivalent weight than that obtained through conventional extraction. The decline in equivalent weight might be due to depolymerization of pectin into pectic acid. Reports by Meilina and Illah (2012) claimed that longer extraction time results in increase in depolymerization of pectin into pectic acid, resulting in decreased esterification of galacturonic acid groups. Putra (2009) reported that the declination of equivalent weight is due to increase in demethylated pectin methoxyl groups, and causes pectin degradation.

Methoxyl percentage indicates the number of methyl ester groups in pectin (Putra, 2009). The methoxyl content is an important factor determining the gel forming ability of pectin.

The methoxyl percentage of pectin obtained through both extraction methods were greater than 7, indicating high methoxyl content (Wignyanto et al., 2014). It was inferred that pectin obtained through PEF and microwave assisted extraction is of desirable purity. Both pectins were classified as high methoxyl pectin.

Galacturonic acid is the major anhydrouronic acid present in pectin. Anhydrouronic acid determination is a major criterion for characterization of pectin (Canteriet al., 2012). Higher galacturonic acid content and lower ash content are major requisite for purity of pectin (Liang et al., 2012). Food and Agricultural Organisation (FAO) suggests a requirement of minimum $65 \%$ of galacturonic acid content for pectin to be pure. The results indicates the pectin obtained through pulsed electric field and microwave extracted pectin sample gave higher percentage of galacturonic acid content, which can be inferred as increase in purity of pectin with pulsed electric field treatment and microwave extraction. The results were comparable with that of commercial sources of pectin such as citrus $(72.1 \%)$ and apple (73.5\%) reported by Savary and Nuñez (2003). The results were comparable with the results (69.47-75.34\%) obtained by Bagherian et al., (2011).

Degree of Esterification is an important quality characteristic that affect the gel formation capability of pectin. Pectin with DE above $50 \%$ is classified as higher ester pectin whereas pectin with DE less than $50 \%$ are classified as lower ester pectin. Decrement in DE \% results in poor settling of gel.The results obtained reveals that pectin obtained through combined PEF and microwave assisted extraction gives higher methoxy pectin which determines the purity and gelling ability of pectin obtained. In this case, both extraction method yielded a DE of higher than $50 \%$ and is graded as higher ester pectin and would result in high gelling power.

The yield of pectin after combined pulsed electric field and microwave assisted extraction yielded $18.3 \%$ at an extraction time of $15 \mathrm{~min}$ whereas conventional extraction yielded $17.1 \%$ pectin after $45 \mathrm{~min}$ of extraction indicating that the tested method of extraction yields higher output with short time of extraction and better energy efficiency. Limited application of heat by combined pulsed electric field and microwave assisted extraction reduces pectin degradation caused by exposure to heat.

High methoxyl pectin of good quality was obtained through the combined process. The moisture content, viscosity, ash content, protein content, equivalent weight, methoxyl percentage, galacturonic acid and degree of esterification of the combined PEF and microwave treated samples showed better 
quality pectin compared to that extracted through conventional extraction.

In conclusion, better quality of pectin was obtained through combined pulsed electric field and microwave assisted extraction of pectin from Jackfruit rind and core with quality characteristics in acceptable range suggested by FAO and Food Chemical Codex. The results indicate the pectin obtained has better gelling properties and can be used in food product preparation.

\section{References}

AOAC (Association of Analytical Chemists), 2000. Official methods of analysis.

AOAC (Association of Analytical Chemists), 2005. Official methods of analysis.

APAARI. 2012. Jackfruit Improvement in the Asia-Pacific Region - A Status Report. Asia-Pacific Association of Agric. Res. Institutions, Bangkok, Thailand. 182p

Bagherian, H., Ashtiani, F.Z., Fouladitajar, A., and Mohtashamy, M. 2011. Comparisons between conventional, microwave-and ultrasound-assisted methods for extraction of pectin from grapefruit. Chem. Eng. and Processing: Process Intensification. 50(11-12): 1237-1243.

Canteri, M.H.G., Scheer, A.P., Ginies, C., Reich, M., Renard, C.M.C.G., and Wosiacki, G. 2012. Rheological and macromolecular quality of pectin extracted with nitric acid from passion fruit rind. J. of Food Process Eng. 35(5): 800-809.

Da Silva, J.L. and Rao, M.A. 2006. 11 Pectins: Structure, Functionality, and Uses. Food polysaccharides and their applications, 353p.

Fishman, M.L., Cooke, P., Hotchkiss, A. and Damert, W., 1993. Progressive dissociation of pectin. Carbohydrate research. 248: 303-316.
Inbaraj, B.S. and Sulochana, N., 2004. Carbonised jackfruit peel as an adsorbent for the removal of $\mathrm{Cd}$ (II) from aqueous solution. Bioresource technology. 94(1): 49-52.

Ismail, N.S.M., Ramli, N., Hani, N.M., and Meon, Z. 2012. Extraction and characterization of pectin from dragon fruit (Hylocereus polyrhizus) using various extraction conditions. SainsMalaysiana. 41(1): 41-45.

Jackson, C.L., Dreaden, T.M., Theobald, L.K., Tran, N.M., Beal, T.L., Eid, M., Gao, M.Y., Shirley, R.B., Stoffel, M.T., Kumar, M.V., and Mohnen, D. 2007. Pectin induces apoptosis in human prostate cancer cells: correlation of apoptotic function with pectin structure. Glycobiol. 17(8): 805-819.

Koh, P.C., Leong, C.M., and Noranizan, M.A. 2014. Microwave-assisted extraction of pectin from jackfruit rinds using different power levels. Int. Food Res. J. 21(5).

Kratchanova, M., Pavlova, E., and Panchev, I. 2004. The effect of microwave heating of fresh orange peels on the fruit tissue and quality of extracted pectin. Carbohyd. Polym. 56(2): 181-185.

Liang, R.H., Chen, J., Liu, W., Liu, C.M., Yu, W., Yuan, M., and Zhou, X.Q. 2012. Extraction, characterization and spontaneous gel-forming property of pectin from creeping fig (Ficus pumila Linn.) seeds. Carbohydrate polym. 87(1): 76-83.

Liu, L., Fishman, M.L., and Hicks, K.B. 2007. Pectin in controlled drug delivery-a review. Cellulose. 14(1): 1524.

Lokhande, A.R., Wani, K.S., and Siddiqui, M.A.S. 2016. Study of Pectin from Peels of Magnifera indica and Artocarpus hetrophyllus. In International Conference on Global Trends in Eng., Technol. and Manag. 
375-381.

Meilina, H. and Sailah, I. 2003. Produksi pectin darikulitjeruk lemon (Citrus medica). Prosiding Simposium Nasional Polimer V.

Muhamadzadeh, J., Sadghi-Mahoonak, A.R., Yaghbani, M., and Aalam, M. 2010. Extraction of Pectin from Sunflower Head Residues of Selected Iranian Caltivers. World Appl. Sci. J. 8: 21-24.

Putra, I.N.K. 2010. Optimasi proses ekstraksi pectin damibuahnangka (Artocarpus heterophyllus Lam k). Agritech. 30(3).

Ranganna, S. 1986. Handbook of analysis and quality control for fruit and vegetable products. Tata McGraw-Hill Education.

Rao, M.A. and Cooley, H.J. 1993. Dynamic rheological measurement of structure development in high- methoxyl pectin/fructose gels. J. of food Sci. 58(4): 876-879.

Savary, B.J. and Nuñez, A. 2003. Gas chromatography-mass spectrometry method for determining the methanol and acetic acid contents of pectin using headspace solid-phase microextraction and stable isotope dilution. J. of Chromatography A. 1017(1-2): 151-
159.

Schmidt, U.S., Koch, L., Rentschler, C., Kurz, T., Endreß, H.U., and Schuchmann, H.P. 2015. Effect of molecular weight reduction, acetylation and esterification on the emulsification properties of citrus pectin. Food biophysics. 10(2): 217-227.

Suhaila, M. and Zahariah, H. 1995. Extraction and characterisation of pectin from various tropical agrowastes. ASEAN Food J. 10(2): 43-50.

Wignyanto, W. and Rahmah, N.L. 2014. The Best Solvent and Extraction Time in Pectin Production made From Waste of Jackfruit (Bark and Straw). Agroindustrial J. 3(1): 141.

Williams, P.A. and Phillips, G.O. 2009. Introduction to food hydrocolloids. In Handbook of hydrocolloids. Woodhead Publishing.1-22pp

Yapo, B.M. 2009. Lemon juice improves the extractability and quality characteristics of pectin from yellow passion fruit byproduct as compared with commercial citric acid extractant. Bioresource Technol. 100(12): 3147-3151.

\section{How to cite this article:}

Nandhu Lal, A. M., M. V. Prince and Sreeja, R. 2020. Studies on Characterization of Combined Pulsed Electric Field and Microwave Extracted Pectin from Jack Fruit Rind and Core. Int.J.Curr.Microbiol.App.Sci. 9(03): 2371-2380.

doi: https://doi.org/10.20546/ijcmas.2020.903.270 